\title{
РЕЛИГИОВЕДЕНИЕ
}

UDC 17:2

\section{The atheism in the worldview of Karl Marx and antitheologism in anarchocollektivism of M. A. Bakunin}

\author{
M. A. Arefiev, A. G. Davydenkova \\ Saint-Petersburg State Agrarian University, \\ 2, Peterburgskoe shosse, Pushkin, St. Petersburg, 196601, Russian Federation
}

For citation: Arefiev M. A., Davydenkova A. G. The atheism in the worldview of Karl Marx and antitheologism in anarchocollektivism of M. A. Bakunin. Vestnik of Saint Petersburg University. Philosophy and Conflict Studies, 2019, vol. 35, issue 1, pp. 186-193. https://doi.org/10.21638/spbu17.2019.115

The article presents a comparative analysis of the atheistic views of Marx and Bakunin. The German philosopher and the Russian anarchist in his youth belonged to this philosophical movement as ladegerate (left Hegelianism). Hegel's dialectics revolutionarily stimulated the thinkers of German, Russian, Polish, Hungarian, Italian and other nations. The inevitable was the split among Hegel's followers on the issue of further trends in historical development. It was the German left Hegelians who started discussing the religious problem. The call of left Hegelians to the philosophy of practical actions have inspired many thinkers, including Feuerbach, Marx, Bakunin, to reconsider the Hegelian philosophy. The atheism of Marx developed on the basis of the study of the materialist doctrines of Epicurus and of Democritus, and anti-theologism Bakunin relied on his understanding of the Church as a tool of autocratic rule. For Marx, atheism had a worldview value, for Bakunin it was a practical task. If in his materialistic philosophy, which was developed in the post-Hegelian period, Marx proceeded in theoretical positions from the category of "alienation", in the early period of his philosophical creativity, the main category was the will. In the further Marx concludes that the elimination of religious alienation involves the abolition of economic alienation. Bakunin's ideal of anarchy as an absence of power suggests other social ties, rather than power, force, control, hierarchy, etc. It is the strongest spiritual and moral basis of common life. This is the existence of a free person in a free society, the reverse side of which is the responsibility of the individual.

Keywords: atheism, anti-theologism, Russian anarchism, philosophy of Marxism, left Hegelianism. 


\section{Introduction}

In the last 2018 year, the public celebrated several anniversaries, among which the most significant was the $155^{\text {th }}$ anniversary of the great Russian philosopher-cosmist and scientist-naturalist Vladimir Ivanovich Vernadsky. As a philosopher, Vernadsky entered our culture because of the doctrine of the noosphere, which he associated with the formation of mankind as a new geological force. And as a biologist and geochemist Vernadsky is known for his works on the biosphere as a sphere of life, which has earthly and cosmic origins. Another, no less significant date was the $200^{\text {th }}$ anniversary of the birth of Karl Marx. The authoritative philosophical dictionary characterizes Marx as a well-known German sociologist, philosopher and economist. Considering human history as a history of struggle between large social groups, the philosophical encyclopedia notes, "Marx came to the conclusion that the evolution of the productive forces of bourgeois society is accompanied by the process (which is contradictory in its own basis) of growth of the wealth of the few and the impoverishment of the proletarian majority. The revolution of the latter, according to Marx, will be for the first time in history the revolution of the majority for all" [1, p. 599].

\section{The concept of "will" in the early Marxian teaching}

The encyclopedic resource gives a general characteristic of Marx in the following words: Karl Marx is a German philosopher, economist, public figure. On the basis of his work there were the following areas:

in science - the scientific method of materialistic dialectics;

in philosophy - materialistic understanding of Hegel's philosophy;

in the social sciences and humanities - materialistic understanding of the history of culture;

in social practice and modern social sciences and humanities - scientific socialism, the first scientific theory of class struggle;

in economics - scientific criticism of political economy, the first scientific theory of surplus value [2].

Describing Marx as a person, encyclopedic sources necessarily point to the philosophical foundations of Marx's teaching, but at the same time, as a rule, do not note his own philosophical works, focusing only on "Capital", "The German Ideology", "Economic and Philosophic Manuscripts of 1844". But the first publication of young Marx was his doctoral dissertation on the history of philosophy "The Difference Between the Democritean and Epicurean Philosophy of Nature" (1841, defended in absentia at the University of Jena). In 1926 it was published in Russian. In his dissertation, Marx positioned himself as a materialist and atheist, although at that time he was under the decisive influence of German classical idealism of Hegel. Marx was the young Hegelian at that time (as, indeed, young Bakunin). For him then philosophy was primarily a tool of theoretical criticism. According to Marx, Clement of Alexandria "turned the Apostle Paul's warning against philosophy in general - into a warning against Epicurean philosophy" [3, p. 159].

Epicurus was an ancient Greek philosopher, the founder of one of the most influential directions in ancient philosophy. In Marx's interpretation, he was an atheist, because he denied the immortality of the soul and the gods in the traditional sense as the gods of 
Olympus, as the opinion of the crowd. Marx writes in his dissertation: "Philosophy, while in its all-conquering and absolutely free heart there is at least one more drop of blood, will always declare with Epicurus... "The wicked is not the one who rejects the gods of the crowd, but the one who joins the opinion of the crowd about the gods". Philosophy does not hide it. The confession of Prometheus: the truth is, all gods I hate, is its own confession, its own aphorism against all heavenly and earthly gods" [3, p. 153].

If in his materialistic philosophy, which was developed in the post-Hegelian period, Marx proceeded in theoretical positions from the category of "alienation", in the early period of his philosophical creativity, the main category was the will. The dialectical scheme of alienation in the young Marx was built under the strong influence of Hegel. He borrowed the very idea of alienation from Feuerbach, who used a dialectical method of thinking about how a person should know the true relationship between himself and God when criticizing religion. But, if Feuerbach's critical analysis of religion is sufficient to overcome the split of human consciousness, Marx concludes that the elimination of religious alienation involves the abolition of economic alienation.

Marx argues in his dissertation, that the philosophy of Epicurus is atheistic, since the world is not created in his conception, it exists in itself, and no external force intervenes during earthly events. The assumption of the gods in Epicurean teaching is nothing more than a tribute to the public opinion of his time. Epicurus was essentially a hidden atheist, although quite inconsistent since he recognized the existence of the gods of Olympus. And his criticism of the divine as a phenomenon was justified by the idea of deviating trajectories of atoms, which made it possible to explain the emergence of free will.

Young Marx sees in the ethics of Epicurus an optimistic, cheerful beginning, which frees a person from superstitions and fatalism, and, ultimately, leads to atheism. Epicurean ethics contains the doctrine of happiness, its conditions and what prevents it. It opens natural beginnings in the world and their connections, and thus frees the soul from oppressive fear, from belief in divine forces, in the immortality of the soul and in the fate gravitating over the person, or destiny. Ethics, therefore, is the teaching of the purpose of life. It can be argued that the atheism of the young Marx was based on ethical principles, on the defining principle of the free will of man, which opposes the determinism and creationism of the divine. Approaching the criticism of religion from the standpoint of historicism, Marx concluded that the emergence of faith in the gods reflected a certain stage in the development of human consciousness, primitive thinking, mythologisation as the main form of spiritual culture. Marx stressed, that in mythology was expressed the attitude of the people or what we now call mentality. It was mythology and myth-making that gave impetus to the emergence of religious ideas.

A detailed analysis of the formation of atheistic ideas of the young Marx is given in the works of the famous St. Petersburg philosopher and religious scholar M. M. Shakhnovich [4]. Describing this stage of life and literary work of Marx as his work as a journalist, she draws attention to the fact that the theme of the philosophy of Epicurus and his atheistic ideas still remains in the field of view of Marx-publicist. "In Roman society, she writes, starting from the headlines of "Kolnische Zeitung", written by Marx, — there has been a tendency of turning vulgarizing Stoicism and Epicureanism to religion. A trend associated with the spiritual need of the educated part of the society in escapism (the desire of the individual to escape from reality. - M.A., A.D.); although Epicureanism in contrast to the other Hellenistic schools have undergone a twofold transformation: on the 
one hand, mingling with the hedonism of Aristippus of Kirena and becoming a sermon of unrestrained pleasures of the flesh, and with another - religion" [4, p. 164].

\section{"Freedom" and "will" in the Bakunin's anti-theologism}

M.A.Bakunin, as a classic of anarchism, was also interested in the natural foundations of the manifestation of freedom of will and choice [5]. Bakunin was not so much a theoretical critic of the religious attitude as an opponent of the religious tools in the form of the Church that organize and support it. Describing the life path and theoretical search for the founder of the Russian classical anarchism Bakunin, modern ethical philosopher writes: "Recognized 'father' of anarchism in Russia is M. A. Bakunin (1814-1876). If you try to take a General look all the way moral, practical and theoretical search of this offspring from Tver' Pryamukhino, the main place there is not anarchy as such. The latter was conceived in later years, mainly as a means of truly liberating of people in society. The ideal, in the end, is a free, thinking and moral person" [6, p. 130].

The world is not only the being of nature but also, above all, social life, cultural and social institutions. The anarchist understood such public institutions as the state, the government and the Church as the bearers of non-freedom. Bureaucracy, both secular and Church, Russian bureaucracy - these are the main objects of criticism. Therefore anarchism and anti-theologism of M. A. Bakunin included not so much atheistic orientation, as social background and anti-etatism. No wonder Bakunin wrote: "If God exists, then man is a slave. Man is intelligent, just, free-so there is no God". As the follower of Bakunin's ideas I.S. Grossman (Roshchin) noted, "the nerve of Bakunin's activity is freedom. According to Bakunin, the enemy of this freedom is a theological idea. Naturally, all that gave weapons against the enemy of freedom, was carefully selected by Bakunin. Many arguments were given materialism; infinitely many he could derive from positivism. It was natural for Bakunin to merge both currents. And it was not as important to harmonize materialism and positivism among themselves, how their hostility to "the third force" $[7$, p. 48], that is, to the theological idea of religion in general, and to the chief tool of religion - the Church.

Bakunin begins his work, which was justifying anti-theologism, with the words: "We are convinced that there has been no major political and social change in the world that has not been accompanied, and often preceded by a similar movement in philosophical and religious ideas that govern the consciousness of both individuals and Society" [8, p.43]. Bakunin's anti-theologism, as a socio-philosophical position, includes an analysis of the epistemological, social and historical background of the origin of religion and its social and cultural role. The spiritual essence of man, the culture of the individual act in the concept of the thinker-anarchist as the unity of the multidimensionality of human existence, and its most important factor is anti-theologism, that is, the freedom of human choice in matters of faith.

According to Bakunin, religion has its primary source in animal life. Russian anarchist adhered to the point of view of the natural causes of the origin of religion. Bakunin considered unconditional and unsubstantiated (irrational) belief in the existence of the supernatural to be a common feature of all religions in the human community. The thinker often quoted in his writings the famous saying of one of the fathers of the Christian Church Tertullian: "I Believe, for it is absurd". It should be noted that this is only a subjec- 
tive scheme of his own understanding of Tertullian's thought. An authentic saying of the latter reads: "That the Son of God died, this is authentically, because it is absurd; that $\mathrm{He}$ was buried, was resurrected, is certain, because that's impossible" [9, p. 368].

Based on ideas about the animal, the natural origin of religion, Bakunin finds its material elements in the instincts of self-preservation, inherent in both the world of animals and human communities. For the animal, as well as for humans, of all instincts, the strongest is the feeling of fear, which, according to Bakunin, is "a kind of ordinary wisdom", that is, a way of self-preservation. Consequently, the feeling of fear gives rise to wisdom, that is, religion. Bakunin believed man is by nature religious, because "he is religious like all other animals but he is the only in this world, who is aware of his religiosity" [8, p.63].

In the work "God and the State" Bakunin emphasizes the moment of the solidity of the natural in relation to the social and the spiritual. The problem of the origin of religious feelings was also considered by Bakunin in historical-epistemological and socio-political terms. In the first the belief in the supernatural acts as a product of the human ability to abstract thinking, with its inherent feelings of imagination and fantasy. And religion arises at the junction of this ability. As the Russian philosopher claimed, all the gods owe their existence to a living sense of imagination, to the play of the imagination. This is a manifestation of the ability of man to reflect reality but at the same time the ability to creation and creativity of reality. The concept of God is an absolute abstraction, the product of human thought, liberated, however, from all real content, turned into an absolute world, into "utter nothingness", or into a single and Supreme Being, that is, God. Bakunin also deduces from anti-theologism atheism, that is, the denial of belief in the super-existent and connects it with a truly free and liberated person.

The second point, socio-political, is based by Bakunin on his analysis of the concept of "power". In the anarchic theory of the thinker, the political-philosophical category of "power" opposes to the universal value - freedom. In 1864 Bakunin has prepared a document entitled "International secret society for the liberation of mankind" (The letter to the Swedish public figure A. Sulman). Researchers of Bakunin's work consider this document as the first theoretical program of bakunism itself [10].

It is possible to allocate the third point in the justification not only of anarchism, but anti-theologism. "Expressing the special tendencies of a certain culture, - the modern researcher writes, - which in many respects is far from the unidirectional Western rationalism, and, trying to reveal the main universal obstacles on the way to the future, the Russian anarchists could look into it not so much from the political and pragmatic positions, as, mainly, from personal, collectivistic, even space positions - far from any rigid bindings to the settled political and ideological conjuncture" [6, p. 126]. In the letterprogram the founder of Russian classical anarchism formulated his point of view on the origin of freedom. Bakunin defines this philosophical category as the degree to which man overcomes the animal nature. It relates freedom and expresses it through the naturalsocial law of solidarity or interrelationship. According to Bakunin, freedom is the law of solidarity. "Freedom is not a restriction, but an affirmation of the freedom of all. This is the law of interrelation" [11, p.271].

In his later works, in particular, "God and the State" (historians know two works by Bakunin under one name as independent parts of one large manuscript), the Russian anarchist points to such a foundation of freedom as 'the natural power of things"'. "Man's freedom consists only in obeying the laws of nature, because the man himself has rec- 
ognized them as such, and not because they were imposed on him from outside by any external will, divine or human, collective or individual" [12, p. 29].

First, the Russian philosopher points to the specifics of individual freedom. According to the modern researcher of the theory of culture V.A. Reshetnikov, "Bakunin's ideas were based on an individualistic interpretation of the romantic (in line with the ideas of German philosophers-romantics - ed.) elitist ideas about the dignity and freedom of the individual, which were the progressive achievement of social thought and sounded especially contrast compared to the conditions of tsarist Russia” [13, p. 147].

Secondly, Bakunin links the problem of freedom with collectivist values. In his opinion, the foundations of freedom lie in the association of individuals. Man becomes man and attains consciousness and realization of his humanity only in society and only through the collective activity of the whole society. The freedom of each individual in this case acts as a result of common solidarity, as a harmony of individual and collective freedom.

Third, the starting point of Bakunin's philosophy of freedom is a practical and moral orientation of man as the highest natural and social being. Man is characterized by the philosopher from the standpoint of the analysis of the creative potential of the individual. Moral and ethical values constitute the spiritual content of a person, serve as a kind of core in a culture of the individual. Bakunin proceeds from the fact that freedom is a generic property of man.

Fourthly, it is a theoretical and practical problem of correlation between freedom and responsibility. Essentially, the ideal of anarchy as absence of power suggests other social ties, rather than power, force, control, hierarchy, etc. It is the strongest spiritual and moral basis of common life. This is the existence of a free person in a free society, the reverse side of which is the responsibility of the individual.

According to modern researchers, we have before us that feature of the philosophy of anarchism, which attracts people to it today. Who are these people? These are actually modern anarchists who stand in opposition to the government and business, who, in their view, are not able to solve global problems by definition. Further, these social philosophers who share the ideas of self-organization and self-government of social life, such as religious philosopher Martin Buber and American-Austrian philosopher Paul Feyerabend, who created the concept of "epistemological anarchism". Finally, this is the large group of people who no longer trust those or other holders of power, but only themselves and society as a whole, in other words, they are anarchists in spirit.

\section{Conclusion}

Summing up the results of our analysis, we note that general, which is a typical for the atheistic views of the founders of such different, at first glance, ideological trends Marxism and collectivist anarchism. First, we must recognize the thorough erudition and deep philosophical basis in the reasoning of both Marx and Bakunin. In the years of their youth, intellectual inquiries and searches lead them to the camp of young Hegelianism or, in the Western philosophical tradition - left Hegelianism. Hegel's dialectics revolutionarily stimulated the thinkers of German, Russian, Polish, Hungarian, Italian and other nations. The inevitable was the split among Hegel's followers on the issue of further trends in historical development. It was the German left Hegelians who started discussing the religious problem. The call of left Hegelians to the philosophy of practical actions have 
inspired many thinkers, including Feuerbach, Marx, Bakunin, to reconsider the Hegelian philosophy.

Secondly, L. Feuerbach, who grew out of the young Hegelian movement imbued with the desire to humanize philosophy, raised the question about the sources and spheres of action of all kinds of alienation, about the earthly roots of human delusions. Thus, not to mention the criticism of idealism, he played an important role in the formation of atheistic views of young Marx and Bakunin. Both pass from the description of the causes and social mechanism of alienation to the analysis of religious alienation.

\section{References}

1. Gritsanov, A. A. (2003), Noveishii filosofskii slovar' [The Newest philosophical dictionary], $3^{\text {rd }}$ ed., Knizhnyi dom Pub., Minsk, Belarus.

2. Wikipedia. (2018), "Marks, Karl" [Marx, Karl], available at: https://ru.wikipedia.org/wiki/Маркс,_ Карл (Accessed 12 April 2018).

3. Marx, K. (1975), "Razlichie mezhdu naturfilosofiei Demokrita i naturfilosofiei Epikura" [The difference between the natural philosophy of Democritus and the natural philosophy of Epicurus], in Marx, K. Sochineniia [Works], $2^{\text {nd }}$ ed., vol. 40, Gosudarstvennoe izdatel'stvo politicheskoi literatury, Moscow, Russia, pp. 147-233.

4. Shakhnovich, M. M. (1986), "Sovremennaia khristianizatsiia filosofii Epikura" [Modern Christianization of Epicurus philosophy], in Religii mira. Istoriia i sovremennost'. Ezhegodnik 1986 [Religion of the world. History and modernity. Yearbook 1986], Nauka, Moscow, Russia.

5. Bakunin, M. (2002), The Philosophical Basis of his Anarchism, by Paul McLaughlin, Algora Publishing, New York, NY, USA.

6. Artemov, V.M. (2007), Svoboda i nravstvennost' [Freedom and morality], Kanon + ROOI "Reabilitatsiia" Publ., Moscow, Russia.

7. Grossman (Roshchin), I.S. (1914), "Bakunin i Bergson” [Bakunin and Bergson], Zavety, vol. 5, pp. 47-62.

8. Bakunin, M.A. (1989), "Federalizm, sotsiologizm i antiteologizm" [Federalism, socialism and antitheologism], in Bakunin, M. A., ed., Filosofiya, sotsiologiya, politika [Philosophy, sociology, politics], Pravda Publ., Moscow, Russia, pp. 11-124.

9. Florenskii, P. A. (1990), Stolp i utverzhdenie istiny [The Pillar and ground of the truth], Pravda Publ., Moscow, Russia.

10. Graham, R., ed., (2005), Anarchism: A Documentary History of Libertarian Ideas (2005), vol. 1: From Anarchy to Anarchism (300CE-1939), Black Rose Books, New York, NY, USA.

11. Bakunin, M. A. (1987), "Mezhdunarodnoe tainoe obshchestvo osvobozhdeniia chelovechestva" [International secret society for the liberation of mankind], in Bakunin, M. A., Izbrannye filosofskie sochineniia i pis'ma [Selected philosophical writings and letters], Mysl', Moscow, Russia, pp. 258-280.

12. Bakunin, M. A. (1918), "Bog i gosudarstvo" [God and the State], Moscow, Petrograd, Russia.

13. Reshetnikov, V.A. (1991), Dukhovnye osnovy sovremennoi politicheskoi kul'tury [The Spiritual foundations of modern political culture], Izdatel'stvo Irkutskogo universiteta, Irkutsk, Russia.

Received: April 30, 2018

Accepted: October 3, 2018

Author's information:

Mikhail A.Arefiev - Dr. Sci. in Philosophy, Professor; mikhail.arefev.49@mail.ru

Antonina G.Davydenkova — Dr. Sci. in Philosophy, Professor; ant-daga@mail.ru 


\section{Атеизм в мировоззрении К. Маркса и антитеологизм}

\section{в анархоколлективизме М.Бакунина}

\section{М. А.Арефьев, А.Г.Давыценкова}

Санкт-Петербургский государственный аграрный университет,

Российская Федерация, 196601, Санкт-Петербург, г. Пушкин, Петербургское шоссе, 2

Для цитирования: Арефьев М.А., Давыденкова А.Г. Атеизм в мировоззрении К. Маркса и антитеологизм в анархоколлективизме М.Бакунина // Вестник Санкт-Петербургского университета. Философия и конфликтология. 2019. Т. 35. Вып. 1. С. 186-193. https://doi.org/10.21638/ spbu17.2019.115 (In English)

В статье дан сравнительный анализ атеистических воззрений К. Маркса и М. Бакунина. Немецкий философ и русский анархист оба в молодости принадлежали к такому философскому течению, как младогегельянство. Гегелевская диалектика революционно стимулировала выдающихся мыслителей немецкого, русского, польского, венгерского, итальянского и других народов. Неизбежен был и раскол среди последователей Гегеля по вопросу о дальнейших тенденциях исторического развития. Именно немецкие младогегельянцы начали обсуждение религиозной проблемы. Призыв младогегельянцев к философии практического действия вдохновил многих, в том числе Фейербаха, Маркса, Бакунина, на глубокую ревизию гегелевской философии. Атеизм Карла Маркса сформировался на основе исследования материалистических учений древнегреческих философов Эпикура и Демокрита, а антитеологизм Бакунина опирался на его представления о церкви как инструменте самодержавной власти. Для Маркса атеизм имел мировоззренческое значение, для Бакунина это была практическая задача. Если в своей материалистической философии, которая разрабатывалась в постгегельянский период, Маркс исходил в теоретических положениях из категории «отчуждение», то в раннем периоде его философского творчества определяющей категорией являлась «воля». В дальнейшем Маркс делает вывод о том, что устранение религиозного отчуждения предполагает отмену экономического отчуждения. Бакунинский идеал анархии как безвластия предполагает иные социальные связи, нежели власть, сила, управление, иерархия и т.д. Это прочнейшие духовно-нравственные основания совместной жизни. Это бытие свободного человека в свободном обществе, оборотной стороной которого выступает ответственность личности.

Ключевые слова: атеизм, антитеологизм, русский анархизм, философия марксизма, младогегельянство (левое гегельянство).

Статья поступила в редакцию 30 апреля 2018 г.; рекомендована в печать 3 октября 2018 г.

Контактная информация:

Арефьев Михаил Анатольевич - д-р филос. наук, проф.; mikhail.arefev.49@mail.ru Давыденкова Антонина Гилеевна - д-р филос. наук, проф.; ant-daga@mail.ru 